\title{
Peran Badan Usaha Milik Desa dalam Pemberdayaan Masyarakat Desa Mungkur Kecamatan Siempat Rube Kabupaten Pakpak Bharat
}

\section{Role of Village Owned Enterprises in Community Empowerment Desa Mungkur Kecamatan Siempat Rube Pakpak Bharat District}

Budi Rasmianto Berutu1, M. Arif Nasution², Heri Kusmanto², Abdul Kadir ${ }^{3}$

1) Magister Program Studi Administrasi Publik, Universitas Medan Area, Indonesia

2) Departemen Ilmu Politik, Fakultas Ilmu Sosial dan Ilmu Politik,

Universitas Sumatera Utara, Indonesia

3) Program Studi Administrasi Publik, Fakultas Ilmu Sosial dan Ilmu Politik, Universitas Medan Area, Indonesia

\begin{abstract}
Abstrak
Penelitian ini bertujuan untuk mendeskripsikan keberadaan badan usaha milik desa di Desa Mungkur Kecamatan Siempat Rube Kabupaten Pakpak Bharat sebagai penguatan ekonomi desa. Hal ini dikarenakan badan usaha milik desa ini adalah salah satu lembaga yang bergerak dibidang sosial dan ekonomi begitu juga sebagai penyedia layanan terhadap masyarakat desa utamanya mengenai bidang usaha. Pembentukan BUMDes di Desa Mungkur ini mengacu pada Peraturan Desa Mungkur Nomor 6 Tahun 2018 Tentang Badan Usaha Milik Desa. Metode penelitian yang digunakan dalam penelitian ini adalah penelitian kualitatif dengan pendekatan deskriptif, dengan fokus penelitian Keberadaan Badan Usaha Milik Desa dalam pemberdayaan masyarakat meliputi pembentukan badan usaha milik desa, mekanisme, bentuk usaha dan pengembangannya dan permodalan, kontribusi keberadaan badan usaha milik desa dalam penguatan ekonomi desa meliputi sumber sumber dana untuk peningkatan pendapatan desa, pemenuhan kebutuhan masyarakat dan pembangunan desa secara mandiri, faktor penghambat dan pendukung keberadaan badan usaha milik desa sebagai penguatan ekonomi desa. Unit-unit usaha yang dilaksanakan oleh BUMDes Desa Mungkur adalah pngelolaan air bersih dan sewa-menyewa peralatan pesta.

Kata Kunci: Peran BUMDEs dalam Pemberdayaan Masyarakat
\end{abstract}

\begin{abstract}
This study aims to describe the existence of a village-owned business entity in the Mungkur Village, Siempat Rube District, Pakpak Bharat Regency as a strengthening of the village economy. This is because this village-owned business entity is one of the institutions engaged in social and economic fields as well as a service provider to rural communities primarily regarding business fields. The establishment of the bumdes in Mungkur Village refers to the Mungkur Village Regulation Number 6 of 2018 concerning Village-Owned Enterprises. The research method used in this study is a qualitative research with a descriptive approach, with a research focus The existence of Village-Owned Enterprises in community empowerment includes the establishment of village-owned enterprises, mechanisms, forms of business and development and capital, contributions of the existence of village-owned enterprises in economic strengthening The village includes sources of funds for increasing village income, fulfilling community needs and independent village development, inhibiting factors and supporting the existence of village-owned enterprises as a strengthening of the village economy. The business units carried out by BUMdes Mungkur Village are the management of clean water and party equipment leases.
\end{abstract}

Keywords: Performance, Service Population Administration.

How to Cite: Berutu B.R, Nasution, M.A, Kusmanto H \& Kadir, A. (2020). Peran Badan Usaha Milik Desa dalam Pemberdayaan Masyarakat Desa Mungkur Kecamatan Siempat Rube Kabupaten Pakpak Bharat. Strukturasi: Jurnal Ilmiah Magister Administrasi Publik, 1(1) 2020: 1-10,

*E-mail: abdullahafifudin@gmail.com

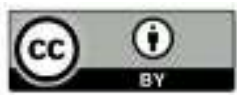




\section{PENDAHULUAN}

Fenomena tentang keberadaan lembaga kemasyarakatan tradisional yang demikian ini adalah bukan hanya merupakan sebuah kebetulan saja, akan tetapi sudah menjadi realita umum di dalam masyarakat. Dimana masyarakat desa ternyata lebih memilih bergabung dan aktif menjadi anggota lembaga kemasyarakatan, Badan usaha milik desa merupakan badan usaha yang di kelola secara mandiri oleh desa, dengan bantuan perangkat desa dan masyarakat (Gowasa \& Ritonga, 2015). Tertuang dalam Undang-undang Nomor 6 tahun 2014 tentang desa diharapkan desa dapat mengelola perekonomian secara mandiri. Desa Mungkur Kecamatan Siempat Rube sudah berdiri Badan Usaha Milik Desa sejak tahun 2016. BUMDes memiliki peran mengatur perekonomian yang ada di desa terutama bidang usaha bisnis penyewaan barang, usaha sosial sederhana, usaha jasa pelayanan, bisnis keuangan secara mikro, usaha bersama masyarakat.

Tujuan akhirnya, BUMDes sebagai instrumen merupakan modal sosial (social capital) yang diharapkan menjadi prime over dalam menjembatani upaya penguatan ekonomi di pedesaan. Untuk mencapai kondisi tersebut diperlukan langkah strategis dan taktis guna mengintegrasikan potensi, kebutuhan pasar, dan penyusunan desain lembaga tersebut ke dalam suatu perencanaan. Perlu memperhatikan potensi lokalistik serta dukungan kebijakan (goodwill) dari pemerintahan di atasnya (supra desa) untuk mengeliminir rendahnya surplus kegiatan ekonomi desa disebabkan kemungkinan tidak berkembangnya sektor ekonomi di wilayah pedesaan. Sehingga integrasi sistem dan struktur pertanian dalam arti luas, usaha perdagangan, dan jasa yang terpadu akan dapat dijadikan sebagai pedoman dalam tata kelola lembaga. Dalam UU Nomor 23 Tahun 2014 tentang Pemerintahan Daerah pada Pasal 213 ayat (1) disebutkan bahwa "Desa dapat mendirikan badan usaha milik desa sesuai dengan kebutuhan dan potensi desa". Substansi UU ini menegaskan tentang janji pemenuhan permintaan (demand complience scenario) dalam konteks pembangunan tingkat desa.

Logika pendirian BUMDes didasarkan pada kebutuhan dan potensi desa, sebagai upaya peningkatan kesejahteraan masyarakat.Berkenaan dengan perencanaan dan pendiriannya, BUMDes dibangun atas prakarsa (inisiasi) masyarakat, serta mendasarkan pada prinsip-prinsip kooperatif, partisipatif, ('user-owned, userbenefited, and user-controlled'), transparansi, emansipatif, akuntable, dan sustainable dengan mekanisme member-base dan self-help.Dari semua itu yang terpenting adalah bahwa pengelolaan BUMDes harus dilakukan secara profesional dan mandiri.

Di Kabupaten Pakpak Bharat upaya menjadikan desa sebagai basis penguatan ekonomi lokal dengan mengembangkan BUMDes sudah berlangsung sejak disahkannya peraturan tentang BUMDes itu sendiri. Hampir setiap Desa di Kabupaten Pakpak Bharat mempunyai pilot project BUMDes. Mengingat badan usaha ini merupakan lembaga ekonomi baru yang beroperasi di pedesaan dan masih membutuhkan landasan yang kuat untuk tumbuh dan berkembang.

Pembangun landasan bagi pendirian BUMDes adalah Pemerintah.BUMDes dalam operasionalisasinya ditopang oleh lembaga moneter desa (unit pembiayaan) sebagai unit yang melakukan transaksi keuangan berupa kredit maupun simpanan. Jika 
kelembagaan ekonomi kuat dan ditopang kebijakan yang memadai, maka pertumbuhan ekonomi yang disertai dengan pemerataan distribusi aset kepada rakyat secara luas akan mampu menanggulangi berbagai permasalahan ekonomi di pedesaan (Lubis, 2014). Salah satu BUMDes yang didirikan Desa Mugkur berdasarkan hasil musyawarah BUMDes Desa Mungkur diberi dengan nama BUMDes Mungkur Nchio. Pendirian dan pengelolaan Badan Usaha Milik Desa di Desa Mungkur berdasarkan Peraturan Desa No. 6 tahun 2018.

Menurut Peraturan Desa Mungkur Nomor 6 tahun 2018 pasal 7 tujuan pembentukan dari Badan Usaha Milik Desa (BUMDes) adalah, sebagai berikut: 1) Meningkatkan perekonomian Desa Mungkur; 2) Meningkatkan pendapatan asli Desa Mungkur; 3) Mengembangkan Potensi Desa Mungkur sesuai dengan kebutuhan masyarakat Desa Mungkur; 4) Menjadi tulang punggung pertumbuhan dan pemerataan ekonomi Desa Mungkur.

Badan Usaha Milik Desa (BUMDes) Desa Mungkur berdiri pada hari Senin, tanggal 06 Oktober 2018. BUMDes didirikan berdasarkan inisiatif pemerintah Desa dan masyarakat Desa Mungkur melalui musyawarah desa (Panjaitan \& Angelia, 2015). Adapun sumber modal BUMDes yaitu: 1) Pemerintah Desa; 2) Tabungan Masyarakat; 3) Bantuan Pemerintah, Pemerinta Provinsi dan Pemerintah Kabupaten.

Di tahun 2018 "BUMDes Mungkur Nchio" menjalankan usaha, meliputi: 1) Usaha bisnis local (social bisnis) sederhana yangmemberikan pelayanan umum (serving) kepada masyarakat dengan memperolh keuntungan social; 2) Usaha bisnis penyewan (renting) barang untukmelayani kebutuhan masyarakat Desa; 3) Unit usaha yang dimiliki BUMDes "Mungkur Nciho" pada tahun 2018 yang telah berjalan sampai saat ini meliputi :

Tabel 1.1.

Nama Jenis Usaha BUMDes Desa Mungkur

\begin{tabular}{ll}
\hline No & Jenis Usaha \\
\hline 1 & Penyewaan Peralatan Pesta \\
2 & Perpipaan serta Pengelolaan Air Bersih \\
\hline & Sumber: Profil BUMDesDesa Mungkur 2018
\end{tabular}

Pertama, Penyewaan Peralatan Pesta, Dengan adanya unit usaha penyewaan Perlatan pesta, dapat meningkatkan Pendapatan asli daerah (PAD) bagi Desa Mungkur. Salah satu kegunaannya adalah apabila masyarakat yang ingin melasanakan pesta, tidak perlu repot menyewa peralatan pesta dari luar yang harganya cukup mahal. Badan Usaha Milik Desa (BUMDes) Mungkur Nchio berhasil memperoleh keuntungan dari penyewaan peralatan pesta tersebut.

Kedua, pengelolaan air bersih. Salah satu BUMDes unggulan di desa Mungkur adalah pengelolaan air bersih. pengelolaan dan pelestarian air di Desa Mungkur yang dijalankan sesuai dengan peraturan perundang-undangan yang berlaku yakni UU No. 7 tahun 2004 tentang Sumber Daya Air yaitu pengelolaan air bersih yang selama ini masyarakat Desa Mungkur harus ke sungai yang jaraknya sekitar $3 \mathrm{Km}$ untuk mengambil air untuk keperluan memasak, mencuci dan sebagainya. Keuntungan yang di dapat dari pengelolan air tersebut disalurkan ke setiap rumah-rumah masyarakat Desa 
Mungkur dan Desa selain Desa Mungkur, oleh karena pengelolanya adalah masyarakat Desa Mungkur sendiri, BUMDes Mungkur Nchio melakukan pengelolaan dengan cara memberdayakan masyarakat Desa Mungkur Sendiri, untuk merawat dan melestarikan pengelolaan air tersebut.

Dana yang dikutip bagi masyarakat luar Desa Mugkur yang ingin di alirkan air ke rumahnya lansung bekisar Rp. 15.000. tidak hanya mendapat kepercayaan dalam mengelola air bersih, dari usaha tersebut BUMDes memperluas ke usaha-usaha lain dan mengembangkannya hingga sekarang. Dengan modal awal Rp 30 juta Simendena bergerak dengan mengelola air bersih, hingga sekarang sudah 210 keluarga yang bergabung dengan BUMDes dari 700 keluarga dengan investasi sekitar Rp 5 juta setiap kepala keluarga sehingga total penyertaan modal dari masyakat mencapai Rp 400 Juta. Melihat fenomena tersebut, maka inilah yang akan diteliti lebih lanjut mengenai pemerataan pemberdayaan masyarakat Desa Mungkur dan pengelolaan BUMDes Simendena dengan semangat kekeluargaan dan gotong royong berdasarkan UU Desa dan peran penting BUMDes Mungkur Nciho dalam meningkatkan kesejahteraan masyarakat desa Mungkur. Penulis tertarik mengkaji lebih lanjut apakah benar BUMDes Mungkur Nciho benar-benar murni dalam pengelolaan masyarakat Desa Mungkur dan pemerintah desa serta keuntungan dari usaha-usaha tersebut yang dapat sampai merata ke masyarakat Desa Mungkur atau tidak.

\section{METODE PENELITIAN}

Berdasarkan masalah yang diangkat dalam penelitian yang menekankanpada proses dan makna, maka bentuk penelitian yang digunakan adalah penelitiankualitatif yang bersifat deskriptif yang bermaksud memberikan gambaran masalahsecara sistematis, cermat, rinci dan mendalam mengenai fenomena yang terjadipada BUMDes Desa Mungkur Kecamatan Siempat Rube Kabupaten Pakpak Bharat ketika. Menurut H.B Sutopo (2002). Penelitian kualitatif lebih menekankan pada makna, lebih memfokuskan padadata kualitas dengan analisis kualitatifnya. Dengan kata lain penelitian kualitatif lebih mementingkan makna, tidak ditentukan oleh kuantitasnya, tetapi lebihditentukan oleh proses terjadinya dan cara memandang atau perspektifnya. Bentuk penelitian ini mengupayakan pencarian data yang berupa kata-katadalam susunan kalimat atau gambar yang berlanjut pada analisis data untukmemberikan gambaran yang senyatanya tentang permasalahan yang ada. Studideskriptif berupaya untuk memperoleh informasi kualitatif dengan pendeskripsianyang teliti, lengkap dan akurat dari suatu situasi. Dalam penelitian ini penulis berupaya menggambarkan bagaimana BUMDes Desa Mungkur Kecmatan Siempat Rube Kabupaten Pakpak Bharat melalui data yangdikumpulkan terutama berupa kata-kata, kalimat atau gambar yang memiliki arti lebih dari pada sekedar angka. Dengan adanya penelitian ini, peneliti dapat menggambarkan secara terperinci tentang pelaksanaan BUMDes Desa Mungkur Kecmatan Siempat Rube Kabupaten Pakpak Bharat.

Untuk memberi pemaknaan atas data atau fenomena yang ditemukan dan dikumpulkan dalam penelitian ini maka dilakukan analisis dengan pendekatan kualitatif dengan eksplanasi bersifat deskriptif. Sebagaimana dikatakan Arikunto (1998), 
penelitian yang menjawab problematika serta ingin mengetahui status dan mendeskripsikan fenomena, lebih tepat digunakan teknik analisis deskriptif kualitatif. Dipilihnya teknik analisis deskriptif kualitatif karena permasalahan atau sasaran penelitian adalah bagaimana BUMDes Mungur Nciho dalam melakukan pemberdayaan terhadap masyarakat Desa Mungkur. Penelitian akan melibatkan pencarian data dari pihak-pihak terkait. Langkah yang ditempuh dengan mengorganisir data berupa gambar, foto, dokumen berupa laporan, biografi, artikel atau buku-buku pedoman dan sebagainya (Moleong, 2001). Data juga diperoleh dari internet atau surat kabar berkaitan dengan masalah. Selanjutnya dianalisis dengan model siklus interaktif sebagaimana dikemukakan oleh Miles dan Huberman (1992). Proses ini dilakukan selama proses penelitian ditempuh melalui serangkaian proses, pengumpulan, reduksi, penyajian, dan verifikasi data.

Reduksi data dimaksudkan sebagai langkah atau proses mengurangi atau membuang data yang tidak perlu, penyederhanaan, memfokuskan, atau menyeleksi untuk menajamkan data yang diperoleh. Penyajian data dimaksudkan sebagai proses analisis untuk merakit temuan data di lapangan dalam bentuk matriks, tabel, atau paparan-paparan deskriptif dalam satuan-satuan kategori bahasan dari yang umum menuju yang khusus.

\section{HASIL DAN PEMBAHASAN}

\section{Gambaran Umum Badan Usaha Milik Desa (BUMDes) Desa Mungkur Kecamatan Siempat Rube Kabupaten Pakpak Bharat.}

Landasan Hukum Pendirian BUMDESDesa Mungkur memiliki latar belakang yuridis yang cukup panjang. Awal berdirinya adalah dengan berdasarkan pada UU No. 32 tahun 2004 tentang Otonomi Daerah, tepatnya di pasal 213 ayat 1, yang isinya adalah; "Desa dapat mendirikan badan usaha sesuai dengan kebutuhan dan potensi desa".

Pasal ini ditindaklanjuti dengan terbitnya Permendagri No. 39 tahun 2010 tentang Tata Cara Pendirian BUMDES. Peraturan ini mengharuskan setiap pemerintah daerah untuk sesegera mungkin menerbitkan peraturan tentang tata cara pendirian BUMDES sesuai dengan karakteristik daerah masing-masing. Jauh sebelum keluarnya Permendagri No. 39 tahun 2010 yang mengharuskan Pemerintah daerah menerbitkan peraturan terkait dengan tata cara pendirian BUMDes, Pemerintah Kabupaten Pakpak Bharat telah menerbitkan Perda No. 5 tahun 2007 tentang Tata Cara Pendirian BUMDES di seluruh desa di Kabupaten Pakpak Bharat. Perda inilah yang menjadi acuan bagi Pemerintah Desa Mungkur untuk mendirikan BUMDes sekaligus dengan Anggaran Dasar dan Rumah Tangga Organisasi (AD/ART).

Pemerintah Desa Mungkur kemudian mengeluarkan Peraturan Desa Nomor 6 Tahun 2018 tentang Pendirian BUMDES yang sekaligus menjadi landasan hukum BUMDESDesa Mungkur.

Desa Mungkur dalam pembentukan BUMDes adalah untuk menampung dan mendorong seluruh kegiatan ekonomi masyarakat, baik yang tumbuh dan berkembang menurut adat istiadat, budaya setempat, maupun kegiatan perekonomian yang 
diserahkan untuk dikelola oleh masyarakat melalui program Pemerintah, Pemerintah Provinsi, dan Pemerintah Kabupaten. Tujuan pembentukan BUMDes adalah untuk: Meningkatkan perekonomian Desa Mungkur; Meningkatkan pendapatan asli Desa Mungkur; Mengembangkan Potensi Desa Mungkur sesuai dengan kebutuhan masyarakat Desa Mungkur; Menjadi tulang punggung pertumbuhan dan pemerataan ekonomi Desa Mungkur.

Modal BUMDesDesa Mungkurdiperoleh dari beberapa sumber diantaranya adalah sebagai berikut: Bantuan dari Pemerintah Pusat, Pemerintah Provinsi, Pemerintah Kabupaten; Pemerintah Desa; Simpanan Masyarakat; Pinjaman dari Lembaga Keuangan Pemerintah, dan atau non Pemerintah; Penyertaan modal dari pihak lain atau kerja sama bagi hasil atas dasar saling menguntungkan

Jenis Usaha BUMDes Desa Mungkur bergerak dalam bidang Jasa, yang mempunyai daerah kerja di wilayah Desa Mungkur dan sekitarnya. Tujuan BUMDes adalah agar semua kegiatan-kegiatan ekonomi desa dapat terlembaga dalam satu wadah

Kepengurusan BUMDes terdiri dari unsur Pemerintah Desa, BPD, Lembaga Desa dan unsur Masyarakat. Dan Masa bakti pengurus BUMDes adalah 3 tahun. Berikut ini adalah komposisi kepengurusan BUMDES Mungkur: Dewan Komisaris/Penanggungjawab dijabat oleh Kepala Desa Ketua BPD; Direksi dijabat oleh Ketua LPMD; Kepala-kepala unit usaha ditetapkan melalui musyawarah pemerintahan desa dan masyarakat; Pembagian Laba Usaha BUMDes Desa Mungkur

Sebagai suatu badan usaha yang dimiliki oleh desa maka BUMDes harus mampu untuk memberikan kontribusi terhadap perekonomian desa. Hal ini sesuai dengan tujuan awal pendirian BUMDes yang termaktub dalam AD/ART BUMDes. Pengelolaan BUMDes harus dilakukan dengan profesional dan mandiri sehingga selain dapat mempertahankan kelangsungan usahanya juga dapat berkontribusi dalam meningkatkan perekonomian di desa. Salah satu caranya adalah dengan mengoptimalkan laba usaha yang dihasilkan BUMDes.

Laba usaha yang dihasilkan biasanya akan dialokasikan untuk memenuhi kebutuhan permodalan dan peningkatan pendapatan desa. Berikut ini adalah persentase pembagian laba hasil usaha BUMDES setiap tahunnya: Pemupukan modal usaha: 40 \%; Pendapatan desa: $20 \%$; Pengurus, kepala unit, pengawas dan karyawan: 30 \%; Pendidikan dan pelatihan: 5 \%; Sosial: 2,5 \%; Cadangan Pangan Pemerintah Desa (CPPD): $2,5 \%$

Persentase pembagian laba usaha sudah dimusyawarahkan bersama antara pemerintah desa, pengelola BUMDes, BPD, dan masyarakat. Pembagian laba usaha ini didasarkan pada azas kemandirian dan kemanfaatanBanyak kebijakan pemerintah yang berorientasi kepada masyarakat kecil yang bertujuan untuk memberdayakan masyarakat, Namun, kebijakan-kebijakan yang sudah ada dirasa belum optimal dampaknya kepada masyarakat kecil. Oleh karena itu pemerintah membuat kebijakan berbentuk lembaga yaitu BUMDes. Organisasi BUMDes menjadi bagian yang sangat penting dalam rangka untuk mendukung pemberdayaan dan penguatan ekonomi kerakyatan.Karena sebagian besar didesa terdapat anggota masyarakat yang tercatat sebagai pengusaha mikro dan kecil yang merupakan tulang punggung perekonomian 
regional dan nasional. Sebagaimana yang telah kita ketahui bahwa telah tumbuh beberapa yang bergerak dibidang jasa disejumlah desa yang dikelola oleh masyarakat walaupun belum dilandasi dengan peraturan yang memadai, secara riil lembagalembaga dilapangan sangat membantu dan dibutuhkan oleh masyarakat terutama yang berpenghasilan rendah guna memenuhi kebutuhan hidup dan pengembangan usahanya.

Pembentukan BUMDes ini merupakan salah satu embiro dan penggerak perekonomian kerakyatan dalam meningkatkan pendapatan masyarakat, untuk memperluas lapangan kerja dan sebagai salah satu upaya pengentasan kemiskinan guna mewujudkan kesejahteraan masyarakat khususnya di pedesaan. Sejalan dengan prinsip Desentralisasi dan Otonomi Daerah, desadiberi kewenangan untuk mengatur dan mengurus kepentingan masyarakat setempat berdasarkan asal usul dan adat istiadat desa setempat, hal ini dimaksudkan untuk mendukung dan menunjang peningkatan pendapatan masyarakat di desa tersebut, maka Peraturan Perundang-undangan memberi peluang bagi pemerintahan desa untuk meningkatkan perekonomiaannya melalui lembaga keuangan di desa dalam bentuk Pengelolahan Badan Usaha Milik Desa (BUMDES).

BUMDES adalah merupakan sebuah instrument pemberdayaan ekonomi lokal dengan berbagai ragam jenis potensi yang dimiliki. Pembentukan BUMDES dimaksudkan untuk menumbuh kembangkan perekonomian desa, meningkatkan perputaran keuangan dan menyelenggarakan kemanfaatan umum baik berupa penyedia berbagai barang dan jasa bagi peruntukan hajat hidup masyarakat serta sebagai perintis bagi kegiatan usaha yang telah ada di desa. Dalam menjalankan kegiatan usahanya BUMDES dapat melakukan kerjasama dengan pihak lain yang didasarkan pada prinsip-prinsip kemitraan yang saling menguntungkan. Disamping itu, keberadaan BUMDES juga dapat memberikan kontribusi bagi peningkatan sumber Pendapatan Asli Desa yang memungkinkan desa mampu melaksanakan pembangunan dan peningkatan kesejahteraan rakyat secara optimal sesuai dengan UU No. 32 Tahun 2004 Pasal 213 ayat 1. Pengembangan BUMDES tidak semata-mata didasarkan padaaspek target pertumbuhan ekonomi, akan tetapi yang lebih penting adalah menciptakan aktifitas ekonomi yang kondusif serta kesejahteraan sosial ditingkat desa paling tidak memecahkan kendala pengembangan usaha desa guna mendorong peningkatan pendapatan masyarakat sehingga dapat mewujudkan kesejahteraan masyarakat secara luas. BUMDES Desa Mungkur ini membentuk unit-unit usaha di dalamnya. Terdapat tiga unit usaha BUMDes Desa Mungkur, tetapi barudua unit usaha yang sudah berjalan secara efektif, yaitu Unit Usaha Pengelolaan Air Bersih Mungur Nciho, dan pengelolaan penyewaan peralatan pesta.

\section{Faktor Pendukung serta Faktor Penghambat dalam pengelolaan BUMDes di Desa Mungkur Kecamatan Siempat Rube.}

BUMDes Desa Mungkur menjadi pembuka bagi keikutsertaan masyarakat secara langsung pada pembangunan melalui pemberdayaan. Hal ini diperkuat dengan persyaratan dalam manajemen program yang mengharuskan adanya keterlibatan 
masyarakat dalam setiap kegiatan yang dilaksanakan (Suharyanto, 2016). Kemauan masyarakat untuk ikut berpartisipasi dalam proses pemberdayaan melalui BUMDes yang hadir di Desa Mungkur tidak lepas dari adanya faktor pendorong. Adapun faktor pendorong partisipasi masyarakat antara lain: Kesadaran masyaraat membangun Desa; Factor dukungan keluarga; Adanya kesempatan keterlibatan perempuan; Faktor Penghambat.

Keterlibatan atau partisipasi masyarakat dalam proses pemberdayaan melalui BUMDes ini tidak hanya berlandaskan pada faktor pendorong saja, tetapi dalam keterlibatannya mereka juga mengalami kendala-kendala. Kendala-kendala ini kemudian akan diuraikan sebagai sub faktor penghambat dalam proses pemberdayaan melalui BUMDes Desa Mungkur adalah Beban ganda yang dimiliki masyarakat

\section{SIMPULAN}

BUMDes Mungkur Nciho dalam memberdayakan masyarakat desa mungkur memiliki dua program unit usaha yaitu unit usaha pengelolaan air bersih dan pengelolaan peralatan pesta. Dari kedua program tersebut Dalam memberdayakan masyarakat desa mungkur, program pemberdayaan masyarakat melalui unit usaha pengelolaan air bersih yang paling dominan untuk saat ini, yang dimana dengan adanya program tersebut diharapkan dapat memberdayakan masyarakat dengan memberikan harapan semua masyarakat desa mungkur mau bersama-sama membantu dan mengembangkannya kepada warga masyarakat desa-desa lainnya yang ada di Kabupaten Pakpak Bharat.

Tujuan program yang dilakukan BUMDes Mungkur Nciho melalui unit usaha pengelolaan air bersih yang bertujuan pemberdayaan ekonomi masyarakat didapat hasil kurang efektif karena pendapatan yang diperoleh warga masyarakat desa mungkur, Pendapatan yang diperoleh belum mencapai kriteria untuk dikatakan berdaya.

Pemantauan program yang dilakukan BUMDes Mungkur Nciho dikatakan belum efektif. Hal ini karena belum ada tindak lanjut yang dilakukan oleh BUMDes Mungkur Nciho terhadap warga yang mendapat tidak ikut serta didalamnya.

Untuk saat ini program pemantauan baru tahap perencanaan. Peran serta masyarakat dalam pengelolaan BUMDes desa mungkur belum menyeluruh baru sebagian masyarakat saja, dan masyarakat juga sudah terlibat dalam program-program yang sudah dijalankan oleh BUMDesa, yaitu dengan cara mengikuti dan menjadi anggota dalam setiap program yang ada. Faktor pendukung optimalisasi fungsi BUMDesa Mungkur Nciho dalam setiap program adalah: Pertama, kebutuhan masyarakat pada aspek kebutuhan dasar. Kedua, pengurangi pengangguran. Ketiga, optimalisasi lahan desa untuk menunjang perekonomian warga. Sedangkan faktor penghambat yang terjadi di lapangan, antara lain: Pertama, kesibukan yang dimiliki oles setiap pengelola BUMDes Kedua, peran ganda yang dimiliki masyarakat dengan mengelola BUMdes. 


\section{DAFTAR PUSTAKA}

Komarudin, (1994), Ensiklopedia Manajemen, Jakarta, Bumi Aksara.

Chambers, Robert, (1995). Poverty and Livelihood: Whose Reality Counts, Discussion Paper 347, Brighton: Institute of Development Studies.

Suyanto, Bagong. (1996). Kemiskinan Dan Kebijakan Pembangunan. Yogyakarta: Aditya Media.

rikunto, Suharsimi. (1998). Prosedur Penelitian Suatu Pendekatan Praktek. Jakarta: PT. Rineka Cipta.

A.M.W. Panarka dan Vidyandika Moeljarto, (1996), Pemberdayaan (Empowerment), Penyunting: Onny S. Prijono dan A.M.W. Pranarka, Pemberdayaan Konsep, Kebijakan dan Implementasi, CSIS, Jakarta

Nasution, S, (2002), Metode Research: Penelitian Ilmiah, Bumi Aksara, Jakarta

Mulyana, D. (2002). Metodologi Penelitian Kualitatif. Bandung: PT Remaja Rosdakarya

Sutopo, H.B. (2002). Metode Penelitian Kualitatif Dasar Teori dan Penerapannya Dalam Penelitian. Surakarta: UNS Press

Soekanto, S. (2003). Sosiologi Suatu Pengantar. Jakarta: PT. Raja Grafindo Persada

Suparjan \& Suyatno, H. (2003). Pengembangan Masyarakat dari pembangunan Sampai Pemberdayaan. Yogyakarta: Aditya Media.

Riduwan. (2003). Metode dan Teknik Menyusun Tesis. Cetakan Pertama. Bandung Alfabeta.

Marbun, B.N. (2003), Kamus Manajemen, Pustaka Sinar Harapan, Jakarta

Bagong, S. J. \& Narwoko, D. (2004). Sosiologi Teks Pengantar dan Terapan. Jakarta: Kencana Media Group.

Subejo dan Supriyanto. (2004), Metodologi Pendekatan Pemberdayaan Masyarakat, Bahan Kuliah: Pemberdayaan Masyarakat Pedesaan, Universitas Gajah Mada Yogyakarta.

Sulistyani, A.T, (2004), Kemitraan dan Model-Model Pemberdayaan. Yogyakarta: Graha Ilmu.

Widjaja, HAW. (2004) Otonomi Desa Merupakan Otonomi yang Bulat dan Utuh. Jakarta, PT. Raja Grafindo Persada.

Suharto, Edi. (2005). Membangun masyarakat memberdayakan rakyat, Bandung: Refika Aditama, 2005.

Wahab, S.A, (2005). Analisis kebijaksanaan: dari formulasi ke implementasi kebijaksanaan negara. Jakarta: Bumi Aksara.

Sumaryadi. (2005). Perencanaan Pembangunan Daerah Otonom dan Pemberdayaan Masyarakat. Jakarta: CV Citra Utama

Suhendra, K, (2006), Peranan Birokrasi Dalam Pemberdayaan Masyarakat, Bandung: Alfabeta

Wasistiono, S. (2006). Prospek Pengembangan Desa. CV. Bandung. Fokusmedia.

Arikunto, S. (2006), Prosedur Penelitian, Suatu Pendekatan Praktik Jakarta: Rineka Cipta.

Moleong, Lexy J., (2006), Metode Penelitian Kualitatif, Remaja Rosdakarya, Bandung

Moleong, Lexy J., (2006), Metode Penelitian Kualitatif, Remaja Rosdakarya, Bandung

Maria Eni Surasih (2006), Pemerintah Desa dan Implementasinya, Erlangga, Jakarta

Adi, I.R. (2008). Intervensi Komunitas Pengembangan Masyarakat sebagai Upaya Pemberdayaan Masyarakat. Jakarta: PT Raja Grafindo Persada.

Sumodiningrat, G., (2009), Mewujudkan Kesejahteraan Bangsa: Menanggulangi Angka Kemiskinan dengan Prinsip Pemberdayaan Masyarakat, Jakarta: PT. Elex Media Komputindo.

Suharto, E. (2009). Membangun Masyarakat Memberdayakan Masyarakat. (Bandung: PT Refika Aditama).

Sugiyono (2010), metode penelitian pendidikan pendekatan kuantitatif, kulaitatif dan R \& D, Bandung : Cv. Alfa Beta,

Azam, A. (2010), Implementasi Pemberdayaan Pemerintah Desa, Pustaka Pelajar, Yogyakarta

Widodo, J. (2010). Analisis Kebijakan Publik. Malang: Bayumedia.

Mardikanto, T. dan Soebianto, P (2012), Pemberdayaan Masyarakat dalam Perspektif Kebijakan Publik, CV Alfabeta, Bandung

Atmojo, S.T. (2015). Peran Badan Usaha Milik Desa (BUMDes) Dalam Pemberdayaan Masyarakat Desa Studi Kasus Pada BUMDes di Desa Temurejo Kecamatan Bangunrejo Kabupaten Banyuwangi". Skripsi, Jember: Fakultas Ilmu Politik dan Ilmu Sosial Universitas Jember.

Uphoff, N. (1986). Local Institutional Development: An Analytical Sourcebook with Cases. West Harford: Kumarian Press.

Dasgupta, P (ed.) \& Serageldin, I (ed.). (1999). Social Capital A Multifaceted Perspective. Washington, D.C: World Bank.

Putnam, R.D. (2000). Bowling Alone: The Collapse and Revival of American Community. New York: Simon \& Schuster. 
Budi Rasmianto Berutu, M. Arif Nasution, Heri Kusmanto \& Abdul Kadir. Peran Badan Usaha Milik

Fukuyama, F. (2002). Trust. Yogyakarta: Qalam. Hooghe, Marc (ed.) \& Stolle, Dietlind (ed.). 2003. Generating Social Capital Civil Society and Institutions in Comparative Perspective. New York: Palgrave Macmillan.

Syahra, R. (2003). Modal Sosial: Konsep dan Aplikasi. Jurnal Masyarakat dan Budaya, Volume 5, No. 1, Tahun

Suharko. (2005). Masyarakat Sipil, Modal Sosial, dan Tata Pemerintahan yang Demokratis. Jurnal Ilmu Sosial dan Ilmu Politik: Volume 8, Nomor 3, Maret 2005 (263-290).

Gowasa, I. \& Ritonga, S. (2015). Implementasi Program Raskin Untuk Membantu Perekonomian Masyarakat Miskin Di Kecamatan Tanah Masa Kabupaten Nias Selatan, Jurnal Administrasi Publik Universitas Medan Area, 3 (2): 97-111

Suharyanto, A., (2016). Surat Kabar Sebagai Salah Satu Media Penyampaian Informasi Politik pada Partisipasi Politik Masyarakat, Jurnal Administrasi Publik, 6 (2): 123-136.

Lubis, Y.A. (2014). Studi Tentang Aktivitas Ekonomi Masyarakat Pesisir Pantai di Pelabuhan, JPPUMA: Jurnal Ilmu Pemerintahan dan Sosial Politik UMA (Journal of Governance and Political UMA), 2 (2): $148-155$

Panjaitan, E. Dewi, R. \& Angelia, N. (2019). Peranan Pemerintah Desa dalam Meningkatkan Kualitas Pelayanan Administrasi kepada Masyarakat. PERSPEKTIF, 8 (1): 32-38.

\section{PERATURAN - PERATURAN}

Undang - Undang Republik Indonesia Tahun 1945

Undang - Undang Nomor 6 Tahun 2014, Tentang Desa

Undang - Undang Nomor 23 Tahun 2014, Tentang Pemerintah Daerah

Peraturan Pemerintah Republik Indonesia Nomor 43 Tahun 2014 Tentang Peraturan Pelaksanaan Undang - Undang Nomor 6 Tahun 2014 Tentang Desa

Peraturan Pemerintah Republik Indonesia Nomor 8 Tahun 2016 Tentang Perubahan Kedua Atas Peraturan Pemerintah Nomor 60 Tahun 2014 Tentang Dana Desa Yang Bersumber Dari Anggaran Pendapatan dan Belanjan Negara

Menteri Dalam Negeri Nomor 39 Tahun 2010 Tentang Badan Usaha Milik Desa

Peraturan Menteri Dalam Negeri Nomor 6 Tahun 2014 tentang Badan Usaha Milik Desa

Peraturan Desa Mungkur Nomor 6 tahun 2018 tentang Pengelolaan Badan Usaha Milik Desa (BUMDes). 